\title{
No Work No Food: An Interpretive Analysis of Paul's Admonition in 2 Thessalonians 3: 6-13 in the Context of the Discourse on Religion and Poverty
}

\author{
Adewale J. Adelakun, PhD \\ Oluseye E. Ajadi, \\ Department of Religious Studies, \\ Obafemi Awolowo University, Ile-Ife, Nigeria
}

Doi:10.19044/esj.2020.v16n23p117 URL:http://dx.doi.org/10.19044/esj.2020.v16n23p117

\begin{abstract}
Linking religion to poverty is not uncommon in the postmodern world. Religious crises, no doubt, are one of the major causes of indescribable suffering and untold hardship in many countries. Ironically, religious people have also been noticed to be happy in the face of poverty, especially, when it is necessitated by their religiosity. For this reason, Marxist philosophy is antagonistic to religion. Marxism argues that religion impoverishes people through its promise of a better place for believers who endure hardship on earth. Religion, Marxists argue, has been used to protect the oppressors while consoling the oppressed. In this regard, religion is described as the opium of the people. This paper agrees with the view that religion can be a spur for poverty. On the other hand, religion can serve as a catalyst for economic development. The second letter of Paul to the Thessalonians 3: 6-13 is interpreted to substantiate these propositions. The paper adopts historicalgrammatical method to interpret the text. The paper points out that some Christians in Thessalonica misunderstood Paul's teaching about the imminence of the parousia, (that is, second coming of Jesus Christ). Consequently, they abandoned their work while waiting for Jesus to come. This compelled Paul to advocate No-Work-No-Food rule. The submission of this paper is that religious role in human development is ambiguous, depending on how religious adherents understand the teachings of their religions.
\end{abstract}

Keywords: Religion and poverty, Paul, indolence, parousia, religion and development, no work, no food 


\section{Introduction}

Poverty is both a universal phenomenon and problem. It is too close to humans to be ignored. That poverty is a bane of many countries has been well documented by scholars who have attributed its causes to various factors such as illiteracy, cultural beliefs, individual deficiencies, irresponsible government, war, and natural disaster. Bradshaw (2006, p. 3) has rightly noted that "explaining poverty remains a lucrative field for academics, policy makers, book publishers, and ideologues, and as a consequence the range of explanations has proliferated." However, it seems poverty has defied all the speeches, writings, researches, donations and commitments of government and non-governmental agencies which have been directed towards it. It is generally believed that poverty cannot be eradicated because it is bred through either incompetency or lack of opportunity. Hence, policy makers now emphasise alleviating it.

It is worthwhile to recognise that poverty "implies a substantial lack at the economic level as well as at social and psychological levels" (Norcia, Rissotto, 2013, p. 180). In other words, it is multi-dimensional. It has economic, social and psychological dimensions which should not be excluded for holistic comprehension. Poverty, in this sense, can be defined as a condition of deprivation or lack of basic needs which is accompanied by social stigma, economic and psychological trauma. As a condition, poverty can increase and decrease. It is not permanent provided right approaches are adopted to fight it. As pointed out in the definition, poverty attracts stigma, economic hardship and psychological trauma. This is best illustrated by a Yoruba witty saying that goes thus, "Aisi owo baba ijaya" meaning literally, "lack of money is the father of all anxiety."

Religion provides another dimension to understanding poverty. For some religious adherents, one of the solutions to solving poverty is to be more religious while antagonists of religion see it (religion) as a major contribution to poverty level in the world. This is the emphasis of the socio-philosophical view of Karl Marx's school of thought which sees religion as a means of annihilating and impoverishing humans. Protagonists of religion like Adam Smith and Max Weber think otherwise. They believed that religion provided a bedrock on which economic development was built. Adam Smith believed that business would not thrive without morality promoted by religion. Leaning on historical and sociological wings, Weber admitted that Puritan teachings influenced the development of capitalism which ushered in economic prosperity in Europe and the entire world (Weber, 1993, [1922]). There is no doubt that certain religious beliefs have been appropriated to promote impoverishment; for example, religious beliefs that promote God/god's favour without hard work, unfettered beliefs in predestination and determinism. 
Paul's message created such a situation in Thessalonica where he had a brief stay and planted a church. Paul's message on the parousia was misunderstood by some who neglected their works while waiting for Jesus' second return (Stacy, 1999, pp. 175-194). Based on this premise, this paper reasserts that religion can cause poverty and impoverish its adherents if and/or when religious teachings are misinterpreted or misunderstood. By implications, religion can also help to alleviate poverty if its message is properly understood. 2 Thessalonians $3: 6-13$ is interpreted through exegesis to establish this claim.

\section{Religion and Poverty}

Writing from a humanist perspective, Merrill Miller (2014) affirmed that religion and poverty are inseparable. Miller's affirmation is based on a research which investigated what most people who lived in the poorest counties in the United States of America searched from Google search engine. The research showed that religious issues such as hell, the rapture and the antichrist dominated their google search. Miller's findings suggest that poor people often find consolation for deprivation in religion. Religion, in this sense, is functional; it gives contentment and security, even in face of predicaments, with the promise of a better place in heaven. There are people who intentionally deprive themselves of material possession and choose to live in penury because of religion. Many religious adherents deprive themselves of food and luxury every year in order to seek the favour of their Supreme Being or deities. There are those who make vows of poverty. There are those who practise asceticism. Such poverty can be referred to as "self-induced poverty." Religion, according to Beyers (2014), "can redirect human thought to spiritual concerns, focusing on spiritual poverty instead of material concerns." Beyers (2014) noted further that religion helps adherents to connect with the spiritual reality. Adherents seek spiritual riches and fulfilment above material possession. Religious people also tend to arrogate poverty and prosperity to the will of God/gods (Nocial \& Rissotto, p. 7).

Writing on the relationship between religion and development, Alkire (2006, p. 1) remarked that "religious people and institutions may be agents of advocacy, funding, innovation, empowerment, social movements, and service delivery. Equally, religious people and institutions can incite violence...oppose empowerment (women should stay at home)...." Alkire's remark suggests that there are religious groups which are disposed to alleviating humans' suffering through their humanitarian efforts while there are others which have destructive tendencies. Arising from the foregoing, it is obviously clear that religion is ambivalent in relations to poverty. It can be a weapon of poverty alleviation and social and economic developments. On the other hands, it can be a catalyst for impoverishing its adherents. 
Religion in Africa reflects above submission. Many wars in the continent, especially, the sub-Sahara region, were caused by religious fanatics. Nigeria, Cameroon, Chad and the Republic of Niger have been dealing with Boko Haram menace since 2009. Many lives and properties have been lost to this crisis. In addition, Mali, Burkina Faso, Somalia and Kenya have witnessed unrest because of religion. Religion has also been used to oppress and subjugate women in some Africa countries. In some religious traditions, women are relegated to the background and treated as men's properties (Herouach, 2019). On the other hand, religion has been on the fore front of the fight against poverty, illiteracy and HIV/AIDS in Africa. It is no gainsaying that schools and hospitals were built by missionaries when they brought Christianity to Africa in the nineteenth century. Today, there are Muslim schools and hospitals as well as commercial banks supporting Africans with capitals for small-scale businesses. Churches have funds through which they empower members. As a matter of fact, religious groups have been more successful in providing health services and alleviating poverty than governments in the post-colonial Africa (Gathogo, 2019).

\section{Paul's Missionary Activities in Acts 17:1-9 and the Thessalonian Correspondences: A Contradiction?}

Acts 17:1-9 contains the narrative of Paul's missionary journey to the Macedonian capital city, Thessalonica. Paul's first place of contact was the synagogue where he was allowed to teach the congregation. According to Luke, many people responded positively to Paul's message, a development which provoked certain Jews who instigated the city authorities against Paul and his co-missionaries. Nevertheless, Paul was able to get some converts before he left Thessalonica for Berea.

Luke's account of Paul's missionary activities in Thessalonica has generated heated controversies among scholars who compare Acts 17 account with Paul's letter(s) to the Thessalonians and conclude that the account is unreliable (Ehrman, 1997, p. 269). Issues raised against Luke's account include lack of quotations from the Old Testament (OT) in the Thessalonian correspondences, which is a surprise considering the fact that Luke claims that Paul preached in the synagogue for three consecutive weeks and some Jews were persuaded. Why did Paul not cite a single verse from the OT to the Jewish Christians in the church? It is also alleged that Paul asserted in 1 Thessalonians 1:9 that the Thessalonians "turned to God from idols" to the gospel. It is somewhat anomalous for Luke to claim that Paul preached in the synagogue at Thessalonica to Jews and God-fearing Gentiles who were not idol worshippers. Lastly, a fault is found with Luke's narrative which appears to stipulate that Paul spent only three weeks in Thessalonica. Compared with Paul's own statement in Philippians 4: 16 where Paul stated that the 
Philippians sent help to him twice while he was in Thessalonica, some scholars are of the view that the Philippians could not have sent help to Paul twice if he only stayed in Thessalonica for three weeks (Simpson, Jr. 2004).

However, these arguments are aptly addressed by Carson and Moo who argued that the issues raised have been overdrawn as there are undeniable similarities between Luke's account and Paul's correspondences to the Thessalonians which cannot be undermined. That Paul preached in the synagogues for three weeks does not mean that he stayed in the city for only three weeks; he could have stayed longer. That Paul did not cite the OT underscores the occasional nature of the letter (Carson, Moo, 2005, p. 533). While establishing that Paul was the writer of the two correspondences to the Thessalonians, Stacy (1999, pp. 180-185) also argued that Paul adopted the Greco-Roman rhetorical style in writing the letters. It is alleged that Paul adopted demonstrative rhetoric for the first letter while the second letter contains deliberative rhetoric. The former involves praises for the good and exhortation against the bad while the latter contains a persuasion against what is not good that needs to be changed. This argument has been refuted by Carson and Moo (p. 533) who could not find any serious trace of GrecoRoman rhetoric in Paul letters. Arguments against Paul's authorship of the 2 Thessalonians have also been countered by Stacy, Carson and Moo, Thiselton and Hagner. In addition, Hagner (2012, pp. 466-467) satisfactorily repudiated the view that 2 Thessalonians should be regarded as the first letter written to the Thessalonians.

\section{Indigenous Religion of Thessalonica}

Thessalonica, the largest city of Macedonia, is dated back to the fourth century B.C. The Romans annexed it in $167 \mathrm{BC}$ and it became a free city in $42 \mathrm{BC}$. It was a cosmopolitan city which was situated on east-west land route which made the city became a natural centre for trade and commerce (Thiselton, 2011, pp. 10-11). The city had a synagogue where Paul and Silas preached before uproar of the Jews forced them out. The city could also boast of variety of religions, including the mystery religions of Dionysus, Serapis, Cabirus and the imperial cult (Thiselton, p. 11). Religion was domesticated in the Greco-Roman world with each nation having its own indigenous religion and gods which were worshipped for the benefits of citizens. In this regard, Stacy's view about the indigenous religion of the Thessalonians and its implications for the membership of the Thessalonian church is worth noting. Contrary to what is stated in Acts 17:4 that "some of them were persuaded and joined Paul and Silas, as did a great many of the devout Greeks and not a few of the leading women" (NRSV), Stacy (p. 185) asserted that the Thessalonian church members were majorly poor indigenous Macedonian people not the 
politarchs (that is, the ruling class which consisted of Roman and Greek immigrants).

The indigenous religion of the Thessalonians was the cult of Cabirus which metamorphosed to the cult of Roma by the leaders of the city in order to please the Romans. The indigenous people were tired of this confused religion and when Paul came with the message that Jesus died and resurrected and would come back into the earth in future, the indigenous people saw some similarities between the cult of Cabirus, their local cult, and Paul's teaching about Jesus. The Macedonians reacted negatively to the merging of the indigenous Cabirus cult with Roma cult which did not go down well with them. In other words, they were receptive to Paul's eschatological teaching which was congruent with the message of their beloved Cabirus cult. They believed Paul's message and were converted. Their conversion, according to Stacy (p. 185), justifies Paul's assertion in 1 Thessalonians that the believers were once idol worshippers who turned to God.

Stacy's thesis sheds light on the religious practices of the Gentiles in Thessalonica prior to their encounter with the gospel. There is no doubt that the classification of other peoples as "Gentiles" by the Jewish people is grossly misleading. It connotes that while the Jews had YHWH as their God other nations, that is, the Gentiles, had only one religion and worshipped the same gods. However, Stacy's submission reiterates the contrary - each nation has their own gods just as Israel had YHWH. For the Thessalonians, it was the Cabirus cult. With Stacy's submission, it is clear that the idols worshipped by the Thessalonians before they converted to Christianity. Nevertheless, good as Stacy's claim may be, it is strange that the cults were not mentioned by both Paul and Luke in their writings.

\section{The Parousia in the Thessalonian Correspondences}

"Parousia" is a Greek word which means presence, advent, arrival or coming of a great person (Louw-Nida, 1989) It is used for the second coming of Jesus. Paul made a case for parousia in his first letter to the Thessalonians (1 Thess 4:13-18). The issued discussed in the passage is commonly referred to as rapture. In the text, Paul allayed the Thessalonians of their grief for their loved ones who died before the parousia by informing them that the dead in Christ have hope just as those who would be alive when Jesus comes back. The Thessalonians were probably confused about the coming of Jesus and the lots of their members who had died. The confusion was probably caused by Paul's inability to adequately address the issue during the short period he was with them. That some false teachers misled the church is also a possible cause for the confusion in the church. Paul made up for his shortcoming by addressing the issue in his first letter. However, this did not solve the problem as the Thessalonians had gone far in their wrong understanding of the parousia. 
Stacy suggested that Paul had given the Thessalonians a kind of teaching which emphasised 'realised eschatology' from which the church concluded that Jesus' coming was imminent and there was no need for them to work. There is no doubt that the Second Coming of Jesus (parousia) was fundamental to Paul's theology.

Moreover, not long after Paul left the Thessalonian church, some of the church members died without witnessing the parousia and thus questions were raised concerning the dead. In summary, the Thessalonians misunderstood Paul's millennial and eschatological message which they probably radicalised and exaggerated. Paul had to write the first letter to correct the anomaly. However, the first letter did not to achieve its purpose; hence, the second letter. The same problem addressed in 1 Thess. is also addressed in 2 Thess. Judy Skeen (1999, p. 287) put it sarcastically thus,

To the followers of Christ in Thessalonica; I 'm sorry that the first dose of medicine did not take. I am sending another so that you will not only live in anxiety and hand-wringing, but so that you may put your hands to work and live well, honouring God for as many days as you have on earth. Grace and Peace, Paul.

The word "parousia" appears in Paul's writings about 14 times.

\section{Paul's No-Work-No-Food Rule: Exegesis of 2 Thessalonians 3:6-13}

${ }^{6}$ Now we command you, brethren, in the name of our Lord Jesus Christ, that you keep away from any brother who lives irresponsibly idle and not according to the tradition that you received from us. ${ }^{7}$ For you yourselves know how you ought to imitate us; we were not idle when we were with you, ${ }^{8}$ we did not eat any one's bread without paying, but with toil and labour we worked night and day, that we might not burden any of you. ${ }^{9}$ It was not because we have not that right, but to give you in our conduct an example to imitate. ${ }^{10}$ For even when we were with you, we gave you this command: If anyone will not work, let him not eat. ${ }^{11}$ For we hear that some of you are living in idleness, mere busybodies, not doing any work. ${ }^{12}$ Now such persons we command and exhort in the Lord Jesus Christ to do their work in quietness and to earn their own living. ${ }^{13}$ Brethren, do not be weary in well-doing.

2 Thessalonians 3:4 gives a hint to what is in 2 Thessalonians 3: 6-13 which deals with "a specific problem in the practical behaviour of part of the congregation" (Menkel, 1994, p. 128). The text indicates that the problem Paul attempted to solve with his first letter was not totally solved. As pointed out earlier, Paul's first letter was not as effective as he would have expected which 
necessitated the second letter. The church had two major problems: improper understanding of Paul's teaching on Jesus' coming and wrong application of the teaching which led to indolence and laziness in the church. A distorted understanding always begets a wrong application.

2 Thessalonians 3:1-5 contains Paul's request for prayer and his commendation for the church in Thessalonica. The Thessalonian believers were commended for their constant obedience to Paul. However, there was a command which had not been fully obeyed by all members. Paul had advised them to avoid laziness and work with their hands. (1 Thess 4:11). Certain members of the church did not heed to Paul's advice. Their indolence precipitated the admonition in 2 Thessalonians 3: 6-13. The pericope (2 Thess. 3: 6-13) is linked with the previous paragraph (2 Thess. 3:1-5) by $\delta \dot{\varepsilon}$, a conjunctive particle which is used to "denote continuation and further thought of development" (Barbara Friberg, Friberg \& Miller, 2000). There is no good reason to dispute the flow of thought in vs. 1-5 where Paul, Silvanus and Timothy requested the church's prayer and also commended them for their obedience. It is to be noted that the word П $\alpha \rho \alpha \gamma \gamma \varepsilon \dot{\lambda} \lambda \mathrm{\alpha} \mu \varepsilon v$ (we command) appears only three times in chapter 3 (vs. 4, 6 and 10). Paul's directive in the text is that the church should keep away or avoid ( $\sigma \tau \varepsilon \dot{\lambda} \lambda \lambda \varepsilon \sigma \theta \alpha$, verb infinitive present middle derived from $\sigma \tau \varepsilon \dot{\varepsilon} \lambda \lambda_{0} \mu \alpha$ ) any member who lives disorderly ( $\alpha \tau \alpha ́ \kappa \tau \omega \varsigma \pi \varepsilon \rho ı \pi \alpha \tau o \tilde{v} \nu \tau \sigma \varsigma$, means to "walk lazily or disorderly or unruly") and

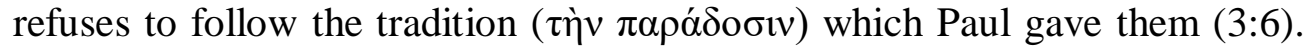
"П $\alpha \rho \alpha ́ \delta o \sigma ı \varsigma "$ in 3:6 does not only suggest teaching passed down from one generation to another, it also includes an action handed down from one generation to another (Friberg, Friberg \& Miller).

Apart from being under Paul's teaching, the Thessalonians also saw a practical example of hard work and assiduity in Paul when he was with them. The culprits in this text were not only idle they were arrogant, unwilling to yield to correction, and were busybodies who meddled with other people's affairs ( $\pi \varepsilon \rho \varepsilon \rho \gamma \alpha \zeta o \mu \varepsilon ́ v o v \varsigma, ~ v .11)$ (Moulton \& Milligan, 1930, p. 505). Craig S. Keener (2014, p. 598) referred to them as busybodies and suggests that they were members who were imitating Cynic philosophers who always begged for food, unlike Paul and his co-travellers who chose to work instead of begging for food. According to Keener (p. 598), it was a usual practice for travelling sage to depend on others for feeding. Similarly, it is possible that the indolent in the church imitated the apostles in Jerusalem who depended on members' generosity. However, that was not the tradition they were to imitate. As Paul's children they were to follow his example (1 Thess 2:7, 20). From Luke's record (Acts 18) Paul made a living by making tents in addition to his missionary activities. As a Rabbi, Paul must have learnt how to combine ministry works together with personal work in accordance with a popular 
aphorism of his time that "Excellent is the study of the Torah together with worldly occupation" (Meggitt, 1998, p. 87).

Paul's directive was given in "the name of our Lord Jesus Christ" which suggests that he expected the Thessalonians to obey it. Commenting on this phrase, Calvin wrote "...this commandment ought to be received with reverence, not as from a mortal man, but as from Christ himself..." 2 Thessalonians 3:6 is the only place in the letter where Paul appealed to a higher authority to reinforce his command. He appealed to the authority of Jesus in three occasions in 1 Thessalonians (4:1, 2 and 5:27). Paul reiterated that he worked hard among the Thessalonians to the extent that he did not eat freely from anybody (vs. 7-9). Paul probably noticed that some of the Thessalonians were not disciplined in their jobs. It might be that some of them were more devoted to their religious services than their careers. They were attending religious meetings when they were supposed to be at their workplaces. Paul reminded them of how he worked both day and night to feed himself ( $\dot{\varepsilon} \nu$ кó $\pi \omega$

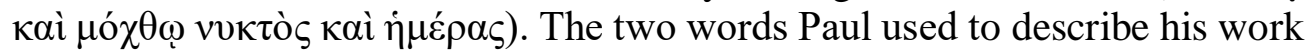
experience, кó $\pi \omega$ каì $\mu$ ó $\chi \theta \omega$, suggest hardship and suffering. He chose hardship instead of the easy way of depending on church's support.

3:11a indicates that there was a report from the Thessalonian church that some members had the tendency of being lazy by substituting hard work with religiosity. Paul reminded them of his command concerning lazy members that "if anyone is not willing to work, let him not eat" ( $\varepsilon$ " $\tau 1 \varsigma$ oủ $\theta \varepsilon \dot{\lambda} \lambda \varepsilon$ $\dot{\varepsilon} \rho \gamma \alpha ́ \zeta \varepsilon \sigma \theta \alpha \imath \mu \eta \delta \dot{\varepsilon} \dot{\varepsilon} \sigma \theta \imath \varepsilon \dot{\tau} \tau \omega)$. This echoes Proverbs 10:4 where it is stated that lazy hands lead to poverty. It is in Jewish traditions to link poverty with laziness. People are poor partly because they are lazy. Commenting on this text, Augustine stated that reading the scripture and praying should not replace work. They are spiritual exercises which should not replace physical work. In the same way, Thomas Aquinas was of the view that Christians are to work while they are on earth, even though they are of the kingdom of God. This is also the view of Luther and Calvin during the Reformation period (Thiselton, 2011, pp. 269-271). There was certainly a welfare package through which the poor in the church were to be catered for. Those who refused to work should be denied access to this package.

It is known from Acts 18:3 that Paul was a tentmaker or a leatherworker, a casual worker. Leather work seems to be lucrative enough for Paul to support his ministry sometimes (2 Thessalonians 3: 8-9). Anthony Thiselton (2000, pp. 23-24) gave a picture of what it meant to be a leather worker and how difficult it could be for Paul to sustain his ministries without assistance. Meggitt's (pp. 75-88) vivid description of economic life in the Greco-Roman period provides a graphic understanding of socio-economic status of Paul and his churches. Paul was by no means a rich person just like many people in his days. He was an ordinary citizen who had to work hard as 
an artisan to feed himself. Paul's economic woe became complicated when he became bi-vocational apostle. Paul depended on assistance from some of his churches and converts who were also assisting him because of their commitment to supplement his income (Phil 4:16; Romans 16:1, 23). The Greco-Roman world was mainly agrarian (Fiensy, 2010, p. 195). But in cities like Thessalonica, there were artisans like Paul, Roman soldiers, plebs, the politarchs, peasants, menial labourers and proletarians. The church in the city was made up of both the rich and the poor (cf. Acts 17:4).

The Thessalonian Christians who refused to work would probably be handful in the church. While Paul would not encourage the church to discontinue the welfare package (which was probably reserved for the elders and teachers/preachers of the gospel, 1 Thess 5:12), those who intentionally refused to work would not be allowed to benefit from it after several warnings he had given them. It is uncertain if all the indolent did so because they were expecting the coming of Jesus. There could be people who were too weak or too sick to work and those who could not find a meaningful job to do. Paul did not consider such people. Stacy (p. 185) suggested that basically the indigenous people of Thessalonica, the Macedonians were poor due to the influence of the Roman and Greek aristocrats who controlled the affairs of the city. The aristocrats, which Stacy (p. 185) referred to as politarchs, were only loyal to the Roman government at the expense of the local and indigenous people. The rich in the church, would then be among the Jewish, Roman and Greek immigrants.

It has been mentioned that the primary reason some believers abandoned their work is their seeming misunderstanding of the message of Paul on the second coming of Jesus. Another way of looking at the issue is the one propounded by Gerd Theissen (1982, p. 28) who focused on the sociology of New Testament. He argued that there were two groups of missionaries in the early Christianity: the itinerant charismatics and community organisers. The former are missionaries who followed Jesus' instruction in the Synoptic gospels that the apostles are to depend on the generosity of others in their missionary journey (Matthew 10: 9-10) while the latter believed that missionaries could support themselves by working. Paul and Barnabas belonged to the community organisers group. If this is applied to the situation in Thessalonica, it means that the 'lazy' believers in Thessalonica followed Jesus' instruction in the synoptic gospels which Paul rejected.

Theissen's interpretation suggests tension between Jesus and Paul's teachings. Nevertheless, the interpretation is congruent with the suggestion of Keener that the unruly believers were imitating the practice of the ancient itinerant philosophers who moved from one place to another and depended on others for their material supplies. Both Theissen and Keener's arguments are plausible but ostensible in this case because of the fact that the believers in 
Thessalonica were not itinerant missionaries. They were converts who could not fully comprehend Paul's theology of the second coming. Besides, Paul is not known for flagrantly disobeying the tradition of Jesus he received. Paul occasionally received support from others (Philippians 4:16). On the other hand, the instruction in the synoptic gospels is specifically for the Twelve and not for all believers, especially, those who were converted outside Jerusalem. Apart from this, it is not totally true that Jesus forbade his disciples from working (cf. Luke 22:35-38). $\pi \alpha \rho \varepsilon \lambda \alpha ́ \beta 0 \sigma \alpha \nu$ (2Th 3:6 BGT) the word is aorist which indicates that Paul once gave them the tradition about how to behave among brethren, probably when he was with them or Paul was referring to his first letter 5:14.

However, there are vicious objections to the traditional or eschatological interpretation of 2 Thessalonians 3:6-13. Colin R. Nicholl (2004, pp. 157-174) succinctly rejected the interpretation because, there is no link between chapter 2 which addresses over-realised eschatology and chapter 3:6-13 which focuses on Paul's chastisement of the idle in the church. This implies that the issue addressed in chapter 2 is not connected in any way with any part of the Thessalonian correspondences. It is also argued that linking laziness with eschatological expectation is not good enough. It portrays Christians expecting the parousia as lazy and indolent.

This position is difficult to uphold considering the fact that 2 Thessalonians 3: 6-11 contains Paul's reference to his missionary activities among the Thessalonians which he encouraged the church to imitate (7-9). This is a clear indication that those indolent Thessalonians were engaged in religious activities like Paul. However, they were not willing to imitate Paul's work ethics. The best way to look at the pericope is to see the problem discussed therein as a consequence of the over-realised eschatological belief of certain members of the church in Thessalonica (Hagner, p. 468).

In summary, the time Paul spent with the Thessalonians was too short for them to understand everything about eschatology and they were also passing through intense persecution which required further instruction from Paul. Hence, he wrote the first letter explaining the parousia briefly and encouraging them to continue in their love for Christ. Paul's letter raised some dust which necessitated the second letter. In the first letter, Paul did not give any order to the church. The ineffectiveness of the first letter warranted the no-work-no-food order as seen in the selected text. It is to be noted the early Christians believed strongly in the imminent coming of Jesus. The impression in all the New Testament books is that Jesus would come in the generation of the early Christians. While other churches founded by Paul did not acted on this expectation, the Thessalonians believed and acted on it - What is the essence of working when Jesus's coming is imminent? 


\section{Conclusion}

From the interpretation of 2 Thessalonians 3: 6-13, it is clear that there is a tendency for religious people to fold arms and be waiting for manna to come down from heaven. This is true of the manner by which religious adherents practise their religions in Africa. Some churches organise 30-day prayer vigil. Miracle services are organised from Monday to Friday during working hours. It is now common to see people go to Prayer Mountains on week days instead of going to their places of work. People abandon their places of work to consult prophets or clerics to collect charms for prosperity. As St. Augustine rightly pointed out, religious activities are not a replacement for diligence; a mistake many religious people make these days. Paul's ethical teachings on diligence are meant to discourage believers from substituting industriousness with indolence. The Jewish people believed that individuals must engage in a trade or manual labour. Laziness was discouraged. This is clearly seen in Paul's assertion that "...we were not idle when we were with you... We worked night and day..." (2 Thessalonians 3: 7-8). As seen in Paul's example, Christianity, as a religion, does not encourage poverty. However, religious-induced poverty is always caused by individuals' misunderstanding of religious messages which empowers their natural inclination to laziness.

\section{References:}

1. Alkire, Sabina. (2006) "Religion and Development," accessed from https://www.ophi.org.uk/wp-content/uploads/Alkire-ReligionDevt.pdf on 18/11/2018

2. Beyers, J. 'The effect of religion on poverty', HTS Teologiese Studies/ Theological Studies 70(1), Art. \#2614, 2014, p. 1. http:// dx.doi.org/10.4102/hts. v70i1.2614

3. Bradshaw, Ted K. (2006). "Theories of Poverty and Anti-Poverty Programs in Community Development," Working Paper Series, RPRC Working Paper No. 06-05, February, pp. 7-25.

4. Calvin's Commentaries, PC Study Bible formatted electronic database Copyright (C) 2005-2006 by Biblesoft, Inc.

5. Carson, D.A. and Moo, Douglas J. (2005). An Introduction to the New Testament, $2^{\text {nd }}$ Edition, Grand Rapids: Zondervan.

6. Ehrman, Bart D. (1997). The New Testament A Historical Introduction to the Early Christian Writings, New York: Oxford University Press.

7. Fiensy, David A. (2010). "Ancient Economy and the New Testament" in Dietmar Neufeld \& Richard E. DeMaris (eds.) Understanding the Social World of the New Testament, New York: Routledge, pp. 194206. 
8. Friberg, Barbara, Friberg, T. and Miller, N.F. (2000). Analytical Lexicon of the Greek New Testament, Grand Rapids: Baker Books, Electronic edition.

9. Gathogo, Julius. (2019). "Steve de Gruchy's Theology and Development Model: Any Dialogue with the African Theology of Reconstruction?.” Stellenbosch Theological Journal, Vol 5, No. 3, pp. 307-328

10. Hagner, Donald. (2012). The New Testament, a Historical and Theological Introduction, Grand Rapids, MI.: Baker Academic.

11. Herouach, Sofian. (2019). "Liberal Feminism Impact on Moroccan Educated Women: Faculty of Letters and Human Sciences, FLDM, as a Field Study." European Scientific Journal, September, Vol. 15, No. 26, pp. 150-192.

12. Keener, Craig S. (2014). The IVP Bible Commentary, New Testament, Second Edition, Downers Grove, IL: InterVarsity Press.

13. Lapin, Daniel. (2014). Business Secrets from the Bible, Spiritual Success Strategies for Financial Abundance, Hoboken, NJ.: Wiley.

14. Louw, Johannes E and Nida, Eugene A. (1989). Greek-English Lexicon of the New Testament Based on Semantic Domains, New York: United Bible Societies.

15. Meggitt, Justin J. (1998). Paul, Poverty and Survival, Edinburgh: T\&T Clarke.

16. Menken, Maarten J.J. (1994). 2 Thessalonians, London: Routledge.

17. Miller, Miller "Why are the Poor More Religious?" accessed from http://thehumanist.com/news/national/why-are-the-poor-morereligious on $27 / 08 / 2014$

18. Moulton, J.H. and Milligan, G. (1930) Vocabulary of the Greek Testament, London: Hodder and Stoughton.

19. Nicholl, Colin R. (2004). From Hope to Despair in Thessalonica, Situating 1 and 2 Thessalonians, Cambridge: Cambridge University Press.

20. Norcia, M. and Rissotto, A. (2013) "How Religious Faith Affects Beliefs in Poverty: A Study in Italy" International Journal of Social Science and Humanity, Vol. 3, No. 2, March, pp. 180-185.

21. Simpson Jr., J.W. (2004). "Thessalonians, Letters to the," Daniel G. Reid (ed.) The IVP Dictionary of the New Testament, Downers Grove, Ill.: InterVarsity Press, pp. 1072-1079.

22. Skeen, Judy. (1999). "Not as Enemy, But Kin: Discipline in the Family of God - 2 Thessalonians 3: 6-10," Review \& Expositor, Vol. 96, No. 2, Spring, pp. 287-294. 
23. Stacy, R. Wayne. (1999). "Introduction to Thessalonian Correspondences", Review \& Expositor, Vol. 96, No. 2, Spring, pp. 175-194.

24. Theissen, Gerd. (1982). The Social Setting of Pauline Epistles, Edinburg: T \& T Clark.

25. Thiselton, Anthony. (2002). The First Epistle to the Corinthians, a Commentary on the Greek Text, Grand Rapids, Williams B. Eerdsman.

26. Thiselton, Anthony C. (2011). 1\&2 Thessalonians through the Centuries, Blackwell Bible Commentary, Chichester: WileyBlackwell.

27. Weber, Marx. (1993). The Sociology of Religion (Boston: Beacon Press, 1993 [1922]) 